\title{
HPLC Profile of Medicinal Plant Extracts and its Application in Aquaculture
}

\section{Yasodha Thirumal ${ }^{*}$ and Suresh Laavu}

Department of Industrial Biotechnology, Shri Andal Alagar College of Engineering, Kancheepuram, Tamil Nadu, India

\begin{abstract}
High Performance Liquid Chromatography technique based screening of medicinal proteins as fish feed were prepared from the selected medicinal plants such as Leucas aspera, Achyranthes splendens, and Swertia chirayita. The present study aims at arrival of quality profile of protein in the medicinal plants which are main ingredients in the fish feed. Antibacterial activity of the medicinal plant extracts was assessed and based on that the self-formulated fish feed was formulated. The medicinal feed surpassed the quality of commercial fish feed by having higher protein and fibre along with medicinal properties. In the present study fish pathogens were isolated from the infected fishes and cultured on a suitable medium. Control of pathogens by $80 \%, 92 \%$ and $87 \%$ Leucas aspera, Achyranthes splendens and Swertia chirayita respectively revealed the efficiency of medicinal plants than the control. This study enabled that the medicated fish feed curtails the high cost of fish diet and can be used as potential high quality alternative source in the aquaculture industry.
\end{abstract}

Keywords: Medicated fish feed; Protein; HPLC; Fish pathogens; Antimicrobial activity

\section{Introduction}

HPLC analytical technique is used for the isolation of various natural products. HPLC is a chromatographic technique that can separate a mixture of compounds and is used in phytochemical and analytical chemistry to identify, quantify and purify the individual components of the mixture [1]. Currently, this technique is gaining popularity among various analytical techniques as the main choice for fingerprinting study for the quality control of herbal plants [2]. Natural products are frequently isolated following the evaluation of a relatively crude extract in a biological assay in order to fully characterize its properties. The resolving power of HPLC is ideally suited to the rapid processing of such multi component samples on both an analytical and preparative scale. Several authors describe the use of HPLC for characterization and quantification of secondary metabolites in plant extracts [3-6].

In the present investigation HPLC technique was used to study the secondary metabolites as medicated proteins from the selected medicinal plants. Medicated proteins were used along with the fishery wastes to prepare the pellets. The self-formulated fish feed made from the extracts of Leucas aspera, Achyranthes splendens and Swertia chirayita leaves and fishery wastes. The medicinal feed surpassed the quality of commercial fish feed by having higher protein and fibre along with medicinal properties. This enabled the fish to combat commonly found fish pathogens in water thereby increasing the survival rate and health of fishes.

\section{Materials and Methods}

\section{Preparation of phyto extracts}

Aqueous extracts of selected plants such as Leucas aspera, Achyranthes splendens and Swertia chirayita were prepared at 1:1 w/v.

\section{Protein extraction using HPLC}

$1 \mathrm{~g}$ of sample was weighed and macerated in pestle and mortar with $5 \mathrm{ml}$ of phosphate buffer, and the contents were transferred to a centrifuge tube. The tube was centrifuged at $8000 \mathrm{rpm}$ for 20 minutes. Supernatant was collected and the extraction was repeated 4-5 times. Supernatant was combined and the volume was made to $50 \mathrm{ml}$ with phosphate buffer. To $5 \mathrm{ml}$ of supernatant, $5 \mathrm{ml}$ of $20 \%$ TCA was added and incubated for half an hour, and centrifuged at $8000 \mathrm{rpm}$ for 20 minutes. Supernatant was discarded, and the pellet was washed twice with acetone, $5 \mathrm{ml}$ of $0.1 \mathrm{~N} \mathrm{NaOH}$ was added to the pellet and mixed well to dissolve the pellet $[7,8]$.

Ion exchange separation: Ion exchange separation is based on the binding of charged sample molecules to oppositely charged groups attached to an insoluble matrix. Substances are bound to ion exchangers when they carry a net charge opposite to that of ion exchanger. This binding is electrostatic and reversible.

Selection of ion exchanger: The $\mathrm{pH}$ value at which a bio-molecule carries no net charge is called the iso-electric point (pI). When exposed to a $\mathrm{pH}$ below its $\mathrm{pI}$, the bio-molecule will carry a net positive charge and will bind to a cationic exchanger. At $\mathrm{pH}$ above its $\mathrm{pI}$, the biomolecule will carry a net negative charge and will bind to an anionic exchanger.

Selection of buffer $\mathbf{p H}$ and ionic strength: Buffer $\mathrm{pH}$ and ionic strength are critical for binding and elution of material in ion exchange chromatography. Selection of appropriate $\mathrm{pH}$ and ionic strength for the start and elution buffers allows the use of 2 possible separation strategies. In the first strategy, binding is achieved by choosing a start buffer with a low $\mathrm{pH}$ for CM Sepharose and high $\mathrm{pH}$ for Q Sepharose fast flow. The ionic strength should be kept as low as possible to allow all components to bind to the ion exchanger. This results in concentration of the target substance and a complete picture of the total sample. In the second strategy, enrichment of target protein is achieved by choosing a start buffer with a $\mathrm{pH}$ optimized to allow maximum binding of target protein, and as high possible as ionic strength to suppress binding of sample contaminants. This strategy results in a concentration of the target substances [9].

*Corresponding author: Dr. Yasodha Thirumal, Department of Industria Biotechnology, Shri Andal Alagar College of Engineering, Kancheepuram, Tamilnadu, India, Tel: 0442756 5662; E-mail:btmbty@gmail.com

Received January 23, 2017; Accepted June 22, 2017; Published June 24, 2017

Citation: Thirumal Y, Laavu S (2017) HPLC Profile of Medicinal Plant Extracts and its Application in Aquaculture. J Aquac Res Development 8: 484. doi: 10.4172/21559546.1000484

Copyright: (c) 2017 Thirumal Y, et al. This is an open-access article distributed under the terms of the Creative Commons Attribution License, which permits unrestricted use, distribution, and reproduction in any medium, provided the original author and source are credited. 
Choice of gradient: Continuous salt gradients are the most frequently used type of elution. Two buffers of different ionic strength, the start and the elution buffer are mixed together and if the volume ratio is changed linearly, the ionic strength changes linearly.

Sample protein purification: Buffers used:

(a) Start buffer: Tris- $\mathrm{HCl}(\mathrm{pH}-9.0): 100 \mathrm{ml}$ of $0.2 \mathrm{M}$ Tris $+10 \mathrm{ml}$ of $0.2 \mathrm{M} \mathrm{HCl}$ diluted to $400 \mathrm{ml}$ of distilled water gives Tris buffer of pH 9.0.

(b) Elution buffer: Tris- $\mathrm{NaCl}$ (pH-8.5): $150 \mathrm{ml}$ of Tris- $\mathrm{HCl}$ (start buffer) $+150 \mathrm{ml}$ of $2 \mathrm{M} \mathrm{NaCl}$ gives Elution buffer.

Samples: Crude protein extracts of medicinal plants $L$. aspera, $A$. splendens, S. chirayita.

Initially the column was washed off the preservatives with $5 \mathrm{ml}$ of $20 \%$ ethanol. The column was washed again with $5 \mathrm{ml}$ of elution buffer. It was equilibrated with $5 \mathrm{ml}$ to $10 \mathrm{ml}$ of start buffer. Sample was applied at a flow rate of $1 \mathrm{ml} / \mathrm{min}$ using a syringe. The column was washed again with $5 \mathrm{ml}$ of start buffer until no material appears in the effluent. The sample was eluted with $5 \mathrm{ml}$ to $10 \mathrm{ml}$ of elution buffer. Continuous gradient elution was performed and the pure protein fractions were collected. After the completed elution, the column was regenerated by washing with $5 \mathrm{ml}$ of elution buffer followed by $5 \mathrm{ml}$ to $10 \mathrm{ml}$ of start buffer.

\section{Protein estimation}

It is the most commonly used method for the determination of proteins in cell free extracts because of its high sensitivity, and quantities as low as $20 \mu \mathrm{g}$ of protein can be measured. Suitable aliquots $(1 \mathrm{ml})$ of the extracts were taken and to them, $4.5 \mathrm{ml}$ of freshly prepared alkaline copper sulphate reagent was added. Folin's reagent was added and the contents were mixed instantaneously. The color was allowed to develop for 10 minutes. The absorbance was recorded at $660 \mathrm{~nm}$ after setting the spectrometer with reagent blank containing $1 \mathrm{ml}$ of $0.1 \mathrm{~N} \mathrm{NaOH}$, instead of sample aliquot. In another set of test tubes, suitable aliquots of BSA solution ( $0 \mu \mathrm{g}$ to $100 \mu \mathrm{g}$ range) were taken. The total volume was made to $2 \mathrm{ml}$ with $0.1 \mathrm{~N} \mathrm{NaOH}$ and the color was developed as before. A standard graph of absorbance at $660 \mathrm{~nm}$ verses $\mu \mathrm{g}$ of BSA was plotted. From the standard graph, the amount of the protein present in the samples was determined [10].

\section{Preparation of medicated feed pellets}

Fresh leaves of Leucas aspera, Achyranthes splendens, and Swertia chirayita were collected from the college campus, air dried for 2 to 3 days and powdered. The dried leaves were ground to a fine powder in a mixer. The dried powder was taken in the following order and proportion $(\mathrm{W} / \mathrm{W})$.

Leucas aspera: Achyranthes splendens: Swertia chirayita (LAS)

- 1:1:1 (LAS)

- 0.5:1:1 (LAS)

- 1:0.5: 1 (LAS)

- 1:1:0.5 (LAS)

Along with $50 \%$ fishery wastes the medicated mix was bound into a thick dough using the gel of Aloe vera as binding agent. The dough was then made into fine uniform pellets which were eventually air dried.

\section{Test on fish pathogens}

The test was conducted with the triplicates of medicinal plant extracts and the commercial fish food (as control) in completely randomized block design. To assess the antimicrobial activity, the samples were subjected to Agar diffusion test and modified Hohenstein test [11]. The fish pathogens were isolated and used in both the tests were Staphylococcus aurues, Staphylococcus epidermidis, Escherichia coli, Pseudomonas species. These species belong to the family of bacteria and they cause most of the diseases in aquaculture. The evaluation of agar diffusion test was made on the basis of zone of inhibition of bacteria around the test sample and the evaluation of modified Hohenstein test was made on the basis of the percentage reduction of bacteria by the sample. Percentage reduction was calculated using the following formula.

$$
R=(B-A) / B
$$

Where $\mathrm{R}$ is percentage reduction, $\mathrm{A}$ is the number of bacteria recovered from the inoculated treated test samples in the jar incubated over the desired contact period (18 hours) and B is the number of bacteria recovered from the inoculated treated test sample swatches in the jar immediately after inoculation i.e., at zero contact time.

\section{Results and Discussion}

\section{HPLC study of medicinal plant materials}

The results pertaining to the HPLC profile of the leaves of Leucas aspera, Achyranthes splendens and Swertia chirayita revealed their highest peaks for the secondary metabolites as protein source. Similar kind of earlier experiments demonstrates the processing of a crude source material to provide a sample suitable for HPLC analysis as well as the choice of solvent for sample reconstitution can have a significant bearing on the overall success of natural product isolation [3]. The source material, e.g., dried powdered plant, will initially need to be treated in such a way as to ensure that the compound of interest is efficiently liberated into solution. In the case of dried plant material, an organic solvent (e.g., methanol, chloroform) may be used as the initial extracting and following a period of maceration, solid material is then removed by decanting off the extract by filtration $[12,13]$. The filtrate is then concentrated and injected into HPLC for separation. The usage of guard columns is necessary in the analysis of crude extract.

The qualitative study of the proteins of the selected phyto extracts was performed by High Performance Liquid Chromatography. The resulting chromatograms were recorded and presented in the Figures 1-3.

\section{Protein profile of different sources of fish feed}

The qualitative analysis was supportive to the quantitative analysis. The protein content of the medicinal plants was purified and taken as pellets along with the fishery wastes. The self-formulated fish feed made from the extracts of Leucas aspera, Achyranthes splendens and Swertia chirayita leaves and fishery wastes contains 97,46.5,84.5 and 69 $\mu \mathrm{g}$ of crude protein Hence the present study confirms the quality and quantity of protein in the fish feed (Table 1). This kind of quality profile is essential in aquaculture industry and many fish farming practices concern about the quality of protein. Commercial protein Jet-X was used to compare the protein profile of fish feed.

Similar studies of Webster et al. [14]; Bai and Gatlin [15] revealed that protein is used for fish growth if adequate levels of fats and carbohydrates are present in the diet. If not, protein may be used for energy and life support rather than growth. Proteins are composed of carbon $(50 \%)$, nitrogen (16\%), oxygen $(21.5 \%)$, and hydrogen $(6.5 \%)$. Fish are capable of using a high protein diet $[16,17]$, but as much as $65 \%$ of the protein may be lost to the environment. Most nitrogen is 


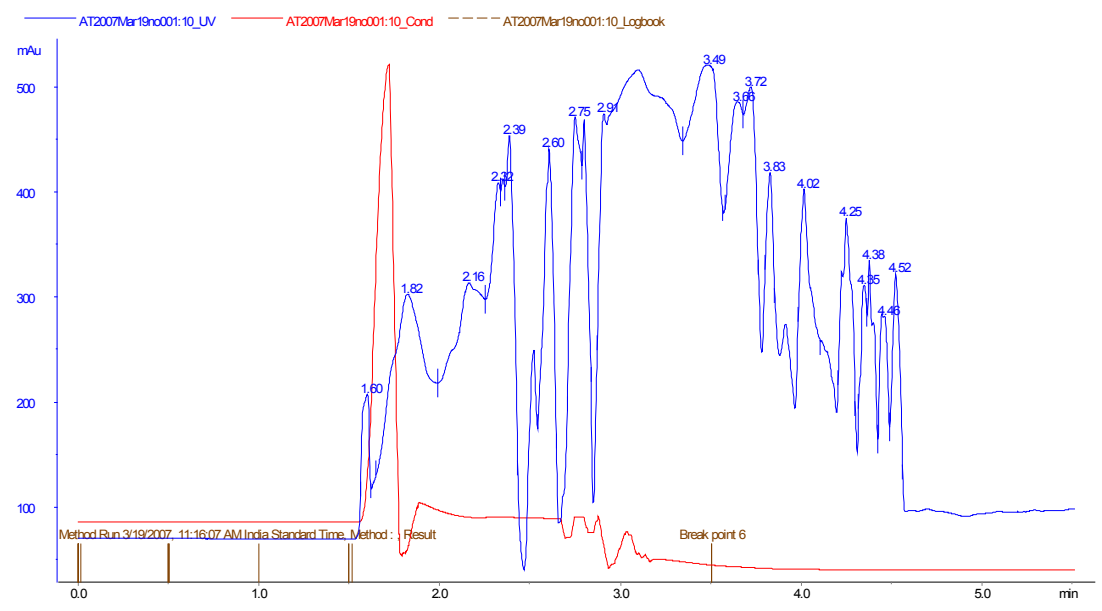

Figure 1: HPLC Chromatogram of protein profile of $L$. aspera.

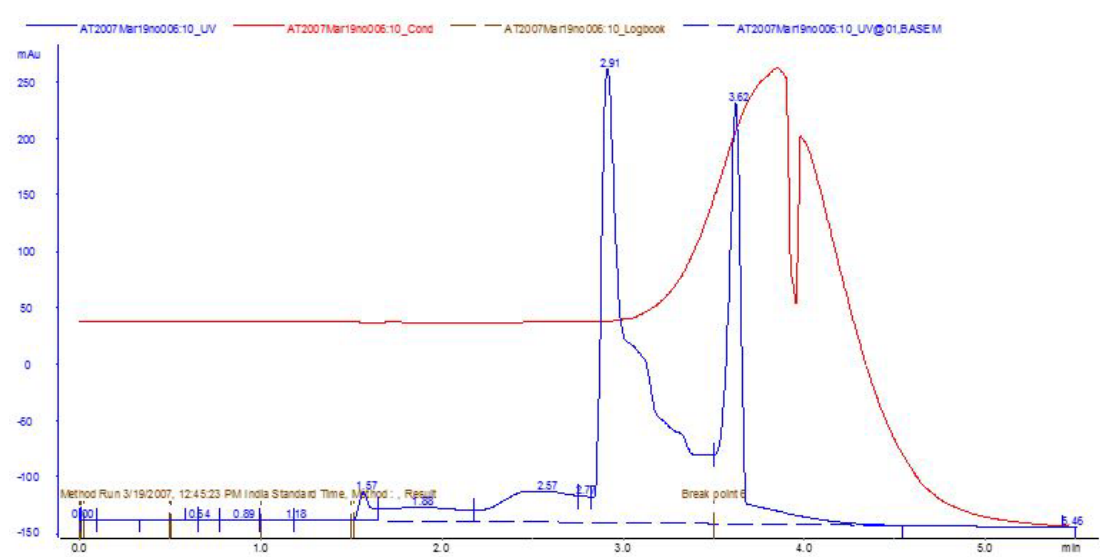

Figure 2: HPLC Chromatogram of protein purification of $A$. splendens.

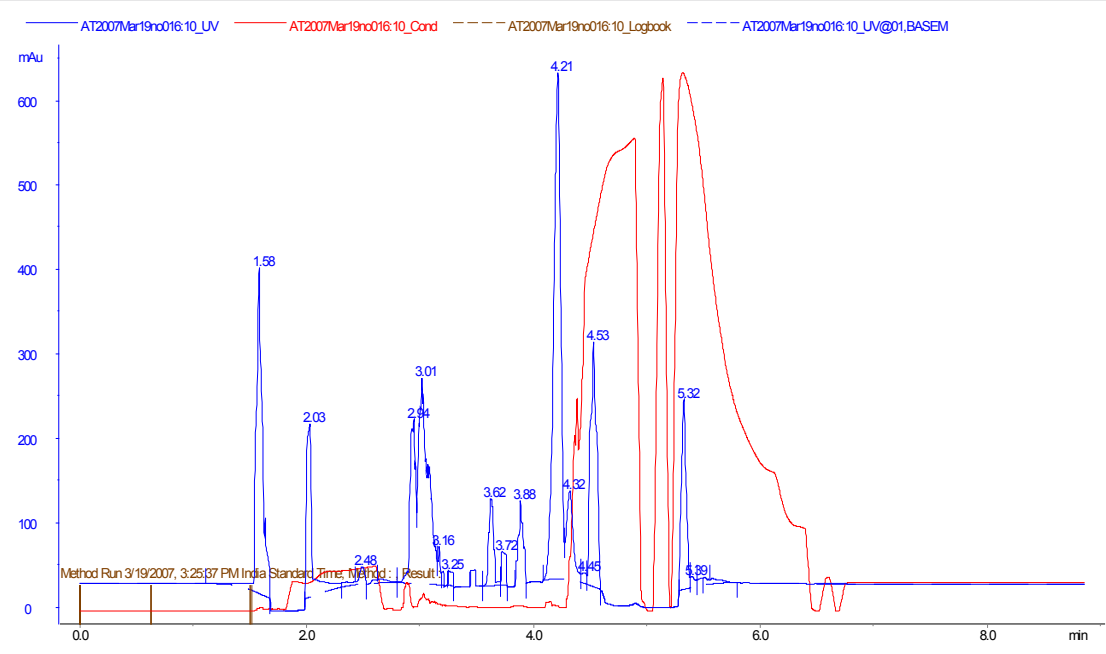

Figure 3: HPLC Chromatogram of protein profile of S. chirayita.

excreted as ammonia $\left(\mathrm{NH}_{3}\right)$ by the gills of fish, and only $10 \%$ is lost as solid wastes.

\section{Antimicrobial activity}

From the results, it was found that the antibacterial effect in terms of percentage reduction for antimicrobial agents treated for different pathogens in the following order:

L. aspera $<$ A. splendens $<$ S. chirayita $<$ commercial fish food (control)

The investigation had been revealed that the minimum quantity of 
Citation: Thirumal Y, Laavu S (2017) HPLC Profile of Medicinal Plant Extracts and its Application in Aquaculture. J Aquac Res Development 8: 484 doi: $10.4172 / 2155-9546.1000484$

Page 4 of 4

\begin{tabular}{|c|c|c|}
\hline S. No & Source & Crude protein content $(\boldsymbol{\mu g} / \mathbf{g})$ \\
\hline 1 & Jet-X fish food & 49.6 \\
\hline 2 & L. aspera & 97.0 \\
\hline 3 & A. splendens & 46.5 \\
\hline 4 & S. chirayita & 84.5 \\
\hline 5 & Fishery wastes & 69.4 \\
\hline
\end{tabular}

Table 1: Crude protein content of commercial fish feed, fishery wastes and the phyto extracts.

\begin{tabular}{|c|c|c|c|c|}
\hline Pathogenic microbes & Leucas aspera $\mu \mathrm{g} / \mathrm{ml}$ & Achyranthes splendens $\mu \mathrm{g} / \mathrm{ml}$ & Swertia chirayita $\mu \mathrm{g} / \mathrm{ml}$ & Jet-X fish food (control) $\mu \mathrm{g} / \mathrm{ml}$ \\
\hline Staphylococcus aurues & $25 \pm 0.03$ & $20 \pm 0.01$ & $20 \pm 0.01$ & $35 \pm 0.01$ \\
\hline Staphylococcus epidermidis & $25 \pm 0.05$ & $25 \pm 0.03$ & $20 \pm 0.01$ & $39 \pm 0.01$ \\
\hline Escherichia coli & $20 \pm 0.03$ & $20 \pm 0.04$ & $20 \pm 0.02$ & $38 \pm 0.02$ \\
\hline Pseudomonas species & $20 \pm 0.02$ & $25 \pm 0.05$ & $20 \pm 0.01$ & $35 \pm 0.01$ \\
\hline
\end{tabular}

${ }^{*}$ Mean of triplicates; \pm Standard deviation

Table 2: Minimum Inhibitory Concentration (MIC) values of medicinal plant extracts.

\begin{tabular}{|c|c|c|c|c|}
\hline Pathogenic microbes & Leucas aspera (\%) & Achyranthes splendens (\%) & Swertia chirayita (\%) & Jet-X fish food (control) (\%) \\
\hline Staphylococcus aurues & $81.0 \pm 0.05$ & $93.5 \pm 0.05$ & $87.0 \pm 0.03$ & $88.2 \pm 0.01$ \\
\hline Staphylococcus epidermidis & $79.5 \pm 0.02$ & $92.5 \pm 0.02$ & $87.5 \pm 0.04$ \\
\hline Escherichia coli & $81.0 \pm 0.02$ & $92.7 \pm 0.01$ & $49 \pm 0.01$ \\
\hline Pseudomonas species & $80.5 \pm 0.03$ & $93.5 \pm 0.02$ & $87.1 \pm 0.03$ \\
\hline *Mean of triplicates; \pm Standard deviation & & & $59 \pm 0.01$ \\
\end{tabular}

Table 3: Confirmation of antibacterial activity by modified Hohenstein test method-Challenge test-Reduction Percentage.

$20 \mu \mathrm{g} / \mathrm{ml}$ to $25 \mu \mathrm{g} / \mathrm{ml}$ was found to increase the antimicrobial activity of the medicinal plants to target the fish pathogens. Whereas the quantity of the commercial fish food (control) was found to be more $35 \mu \mathrm{g} / \mathrm{ml}$ to $39 \mu \mathrm{g} / \mathrm{ml}$ to control the fish pathogens. Hence the results for the antimicrobial test (Table 2) and modified Hohenstein test (Table 3) were confirmed the viability of the antimicrobial treatment when it is used as fish feed.

Similar experiments were conducted using different plant materials as protein sources [18-20] and to control different pathogenic bacteria [21].

\section{Conclusion}

To isolate and purify the plant based products like secondary metabolites and proteins HPLC is highly useful for researchers and industrialists those who focus on quality. Hence from the present experiments it is concluded that the protein content of Leucas aspera, Achyranthes splendens and Swertia chirayita and fishery wastes could be used as high protein alternative sources of fish feed. Medicated fish feed curtails the high cost of fish diet and can be used as potential high quality alternative source in the aquaculture industry.

\section{References}

1. Ahuja S (2006) High Pressure Liquid Chromatography. Comprehensive Analytical Chemistry. Elsevier

2. Fan XH, Cheng YY, Ye ZL, Lin RC, Qian ZZ (2006) Multiple chromatographic fingerprinting and its application to the quality control of herbal medicines. Anal Chim Acta 555: 217-224.

3. Cannell RJP (1998) Natural Products Isolation. Human Press Inc. New Jersey.

4. Martin M, Guiochon G (2005) Effects of high pressure in liquid chromatography. J Chromatogr A 1090: 16-38.

5. Janovik V, Boligon AA, Athayde ML (2012) Antioxidant activities and HPLC/DAD analysis of phenolics and carotenoids from the barks of Cariniana domestica (Mart.) Miers. Res J Phytochem 6: 105-112.

6. Piana M, Zadra M, De Brum TF, Boligon AA, Gonçalves AF, et al. (2013) Analysis of rutin in the extract and gel of Viola tricolor. J Chromatogr Sci 51 406-411.

7. Tacon AGJ, Haaster JV, Feathstone PB, Kerr K, Jackson AJ (1994) Studies on the utilization of full-fat soybean and solvent extracted soybean meal in a complete diet for rainbow trout 49: 1437-1443.

8. Windsor ML (2001) Fish protein concentrate. Food and Agricultural Organization of United Nations, Torry Research Station, Torry Advisory Note No. 39

9. Cho CY (1985) Effects of protein intake on metabolically and net energy value of fish diet $\mathrm{Pp}$ in nutrition and feeding in fish: Academic Press, London, UK.

10. Ghaly AE, Ramakrishnan VV, Brooks MS, Budge SM, Dave D (2013) Fish processing wastes as a potential source of proteins, amino acids and oils: A critical review. J Microb Biochem Technol 5: 4

11. National Committee for Clinical Laboratory Standards (NCCLS) (1999) Methods for determining bactericidal activity of antimicrobial agents. Approved guideline M26-A. Wayne, USA

12. Bhosale SV, Bhilave MP, Nadaf SB (2010) Formulation of fish feed using Ingredients from plant sources. Research Journal of Agricultural Sciences 1 : 284-287.

13. Hernandez MD, Martinez FJ, Jover M, Garcia B (2007) Effects of partia replacement of fish meal by soybean meal in sharpsnout seabream (Diplodus puntazzo) diet. Aquaculture 263: 159-167.

14. Webster CD, Tidwell JH, Yancey DH (1992) Effect of protein level and feeding frequency on growth and body composition of cage reared channel catfish. The Progressive Fish-Culturist 54: 92-96.

15. Bai SC, Gatlin III DM (1992) Dietary rutin has limited synergistic effects on vitamin C nutrition of ingerling channel catfish. Fish Physiol Biochem 10: 183-188.

16. Ramachandran S, Ray AK (2004) Inclusion of extruded grass pea Latgyrus sativus seed meal in compound diets for Labio rohita (Hamilton, 1992) fingerlings. Aquaculture Ichthyol Piscatorial 34: 205-218.

17. Storebakken T, Refsite S, Ruyter B (2000) Soya products as fat and protein sources in fish feeds for intensive Aquiculture. Soy in Animal Nutrition. Fed Anim Sci Soc Savoy IL: 127-170.

18. Guyton JR, Bays HF (2007) Safety consideration with niacin therapy. Aquaculture Journal Cardio 9: 22-31.

19. Glencross BD, Booth M, Allan GL (2007) A feed is only as good as its ingredients: A review of ingredient evaluation strategies for aquaculture feeds. Aquacult Nutr 13: 17-34.

20. Hardy RW (1996) Alternative protein source for salmonand trout diets. Anim Feed Sci Tech 59: 71-80

21. Dorman HJD, Deans SG (2002) Antimicrobial agents from plants, antibacterial activity of plant volatile oils. J Appl Microbiol 88: 2-38. 